\title{
Assessing the importance of Isle of Man waters for the basking shark Cetorhinus maximus
}

\author{
Haley R. Dolton ${ }^{1,2}$, Fiona R. Gell ${ }^{3}$, Jackie Hall ${ }^{4}$, Graham Hall ${ }^{4}$, Lucy A. Hawkes ${ }^{1}$, \\ Matthew J. Witt ${ }^{1,2, *}$ \\ ${ }^{1}$ University of Exeter College of Life and Environmental Sciences, Hatherly Laboratories, Prince of Wales Road, Exeter EX4 4PS, UK \\ ${ }^{2}$ University of Exeter, Environment and Sustainability Institute, Penryn Campus, Cornwall TR10 9FE, UK \\ ${ }^{3}$ Department of Environment, Food and Agriculture, Thie Slieau Whallian, Foxdale Road, St John's IM4 3AS, Isle of Man \\ ${ }^{4}$ Manx Basking Shark Watch, Glenchass Farmhouse, Port St Mary IM9 5PJ, Isle of Man
}

\begin{abstract}
Satellite tracking of endangered or threatened animals can facilitate informed conservation by revealing priority areas for their protection. Basking sharks Cetorhinus maximus $(\mathrm{n}=11)$ were tagged during the summers of 2013, 2015, 2016 and 2017 in the Isle of Man (IoM; median tracking duration $378 \mathrm{~d}$, range: 89-804 d; median minimum straight-line distance travelled $541 \mathrm{~km}$, range: 170-10 $406 \mathrm{~km}$ ). Tracking revealed 3 movement patterns: (1) coastal movements within IoM and Irish waters, (2) summer northward movements to Scotland and (3) international movements to Morocco and Norway. One tagged shark was bycaught and released alive in the Celtic Sea. Basking sharks displayed inter-annual site fidelity to the Irish Sea $(n=3)$, a Marine Nature Reserve (MNR) in IoM waters $(n=1)$, and Moroccan waters $(n=1)$. Core distribution areas $(50 \%$ kernel density estimation) of 5 satellite tracked sharks in IoM waters were compared with 3902 public sightings between 2005 and 2017, highlighting west and south coast hotspots. Location data gathered from satellite tagging broadly correspond to the current boundaries of MNRs in IoM waters. However, minor modifications of some MNR boundaries would incorporate $20 \%$ more satellite tracking location data from this study, and protective measures for basking sharks in IoM waters could further aid conservation of the species at local, regional and international scales. We also show the first documented movement of a basking shark from the British Isles to Norway, and the longest ever track for a tagged basking shark ( 2 yr and 2 mo, $804 \mathrm{~d}$ ).
\end{abstract}

KEY WORDS: Satellite tracking $\cdot$ Basking shark $\cdot$ Cetorhinus maximus $\cdot$ Public sightings $\cdot$ MPA $\cdot$ Spatial ecology $\cdot$ Irish Sea $\cdot$ Isle of Man

\section{INTRODUCTION}

Many animal taxa, including birds, fish and mammals, seasonally migrate to make use of natural fluctuations in available resources that are needed to support growth and reproduction, and to avoid harsh environmental conditions and predators (Hawkes et al. 2011, Hopcraft et al. 2014, Hammerschlag et al. 2015, Leroy et al. 2016, Peiman et al. 2017). Moreover, many species display site fidelity, returning to the same area annually in search of profitable re-

${ }^{*}$ Corresponding author: m.j.witt@exeter.ac.uk sources (Wege et al. 2016). Although major gains have been made in understanding the movements of many terrestrial (Kays et al. 2015) and marine taxa (Godley et al. 2008, Hussey et al. 2015, Hays et al. 2016), some large marine vertebrates present a challenge to study due to the difficulties of tracking species that spend extensive periods of time underwater. Recent advances in satellite tracking technology, including smaller devices and less invasive attachment techniques, mean that insightful data can now be obtained and used to explore the drivers of migra-

() The authors 2020. Open Access under Creative Commons by Attribution Licence. Use, distribution and reproduction are unrestricted. Authors and original publication must be credited. 
tory movements for conservation benefit (Greene et al. 2009, Hammerschlag et al. 2011, Fossette et al. 2014), with basking sharks recently cited as an example of tracking data successfully influencing policy (Witt et al. 2016, Hays et al. 2019).

The need for greater understanding of migration patterns and drivers is particularly pertinent to elasmobranch species whose populations are undergoing global declines due to overfishing and incidental bycatch in non-target fisheries (Dulvy et al. 2014). Marine protected areas (MPAs) have been demonstrated to benefit many different marine species and habitats (Angulo-Valdés \& Hatcher 2010), but are less effective with highly mobile species (Hooker \& Gerber 2004) and so can only offer protection from anthropogenic threats if they use the best available evidence (Runge et al. 2014). Technologies such as satellite tracking can aid informed design and management of MPAs, as successful designation relies on good biological knowledge of the core activity areas, or hotspots, of a species (Doherty et al. 2017b).

Basking sharks are the second largest fish in the world, have a circumglobal distribution and a low worldwide genetic diversity (Hoelzel et al. 2006), as is observed for a range of large pelagic migratory sharks (Schmidt et al. 2009, Blower et al. 2012), and are capable of transoceanic migrations (Gore et al. 2008). Norwegian, Scottish and Irish fishing fleets historically exploited basking sharks for their highly prized squalene-containing livers as well as for their fins and meat. As a result, local populations have been dramatically reduced in the North-East Atlantic (Kunzlik 1988). Although targeted fisheries are no longer in operation, basking sharks are at risk of bycatch by surface and bottom set gill nets and trawls (Berrow 1994, Berrow \& Heardman 1994, Francis \& Duffy 2002), and are also at risk from vessel strikes (Speedie et al. 2009) and the shark fin trade (Clarke et al. 2007). There is also emerging evidence that these filter feeders can ingest micro-plastics, which may lead to the bio-accumulation of associated toxins (Fossi et al. 2014). Basking sharks are listed as 'Endangered' globally by the International Union for Conservation of Nature (IUCN) (Rigby et al. 2019).

The Isle of Man (IoM), located in the Irish Sea, is well known as a basking shark hotspot during the months of May to August (Witt et al. 2012, Hall et al. 2013, Austin et al. 2019), and behaviours thought to be important for breeding, including nose-to-tail following and breaching, are regularly observed (Hall et al. 2013). The IoM is the only entire jurisdiction to be designated as a UNESCO Biosphere Reserve, of which basking shark research and conservation make an important contribution. In IoM waters, basking sharks are protected under Schedule 5 of the Manx Wildlife Act 1990 (for other legislation and international treaties, see Table S1 in the Supplement at www.int-res.com/articles/suppl/n041p209_ supp.pdf). It is not clear whether basking sharks observed in IoM waters (within 12 nautical miles [nmi] of the IoM) are resident, remaining in a defined area for a period of time (Speed et al. 2011), or transient, returning to specific locations after a continued absence (Chapman et al. 2015). The IoM Government has recently (September 2018) declared 9 dedicated Marine Nature Reserves (MNRs), which in part acknowledge IoM waters as a basking shark hotspot and include basking sharks as conservation features. MNRs are protected from trawling and dredging, and additional management measures are in development.

The present study used satellite tracking to (1) spatio-temporally delineate local basking shark hotspots, (2) determine whether intra- and inter-annual site fidelity of basking sharks occurs and (3) investigate the spatial efficacy of new MNRs in IoM waters and their potential role in conferring protection for the basking shark.

\section{MATERIALS AND METHODS}

\subsection{Tag attachment and specification}

Satellite tagging was conducted under licence from the IoM Department of Environment, Food and Agriculture under the Manx Wildlife and Countryside Act 1990. Eleven Smart Position or Temperature tags (SPOT Wildlife Computers) were attached to basking sharks in IoM waters by the Manx Basking Shark Watch (MBSW) team during June and August 2013 ( $\mathrm{n}=5), 2015(\mathrm{n}=3), 2016(\mathrm{n}=2)$ and 2017 ( $\mathrm{n}=1$ ). Three of the tagged basking sharks were female and 8 were male; their size varied from 5 to $8 \mathrm{~m}$ in length $(5-6 \mathrm{~m}, \mathrm{n}=4 ; 6-7 \mathrm{~m}, \mathrm{n}=5$ and $7-8 \mathrm{~m}, \mathrm{n}=2$; Table 1). Satellite tags were deployed on basking sharks using a titanium M-style dart (Wildlife Computers), attached by a stainless steel flexible cable covered in heat-shrink tubing, a swivel and monofilament line, which attached to the tag. This was deployed into the sub-dermal layer at the base of the first dorsal fin using a modified extendable pole spear. SPOT tags transmitted to satellites carrying Argos System receivers and detected transmissions were used to determine location estimates of individual basking sharks during 


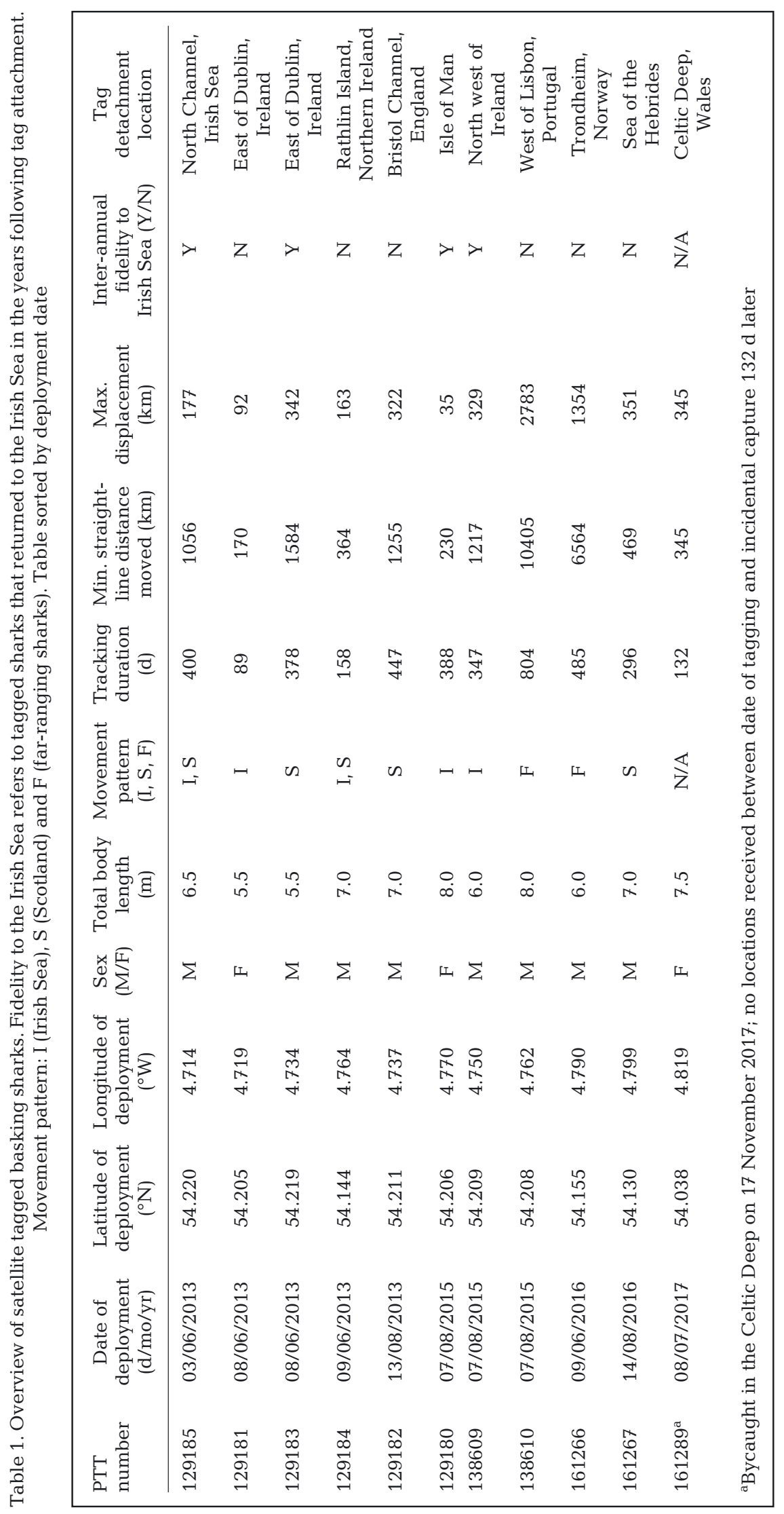

surfacing events. The study area was overpassed by these satellites 30 to 40 times per day for $\sim 10$ min each.

\subsection{Location data filtering and analysis}

Estimates of shark location were downloaded from CLSArgos and archived using the Satellite Tracking and Analysis Tool (STAT) (Coyne \& Godley 2005). Argos data were filtered in R ( $R$ Development Core Team 2016) using the package argosfilter (Freitas 2012) to include location classes 1 (accurate to 500-1500 m), 2 (accurate to 250$500 \mathrm{~m}$ ), 3 (accurate to $<250 \mathrm{~m}$ ) and A (3 satellite messages received but no accuracy estimation) (Witt et al. 2010). Data were filtered further to exclude maximum speeds between 2 locations that exceeded $10 \mathrm{~km} \mathrm{~h}^{-1}$, maximum angles that exceeded $15^{\circ}$ and $25^{\circ}$ and minimum angle distance 2500 and $5000 \mathrm{~m}$, respectively to remove unrealistic estimated movements. Filtered shark locations and connecting line shapefiles were produced using the package rgdal (Bivand et al. 2018). Cumulative distance travelled by tagged basking sharks and maximum displacement were calculated using the package geosphere (Hijmans et al. 2017). Kernel density estimation (KDE) with and without barriers and mapping was performed using ESRI ArcGIS version 10.5.1.

Two sharks (138610, 161266) underwent several long-range movements lasting multiple months while producing no location estimates; as such, the filter set for these sharks was modified to use Argos location classes 3, 2, 1, A and B (1-2 messages received but no accuracy 
estimation); however, speed, turning angle and distance filter were not applied, ensuring infrequent location data were not inappropriately filtered.

Sex- and size-based dispersal have been reported for large shark species such as great white sharks Carcharodon carcharias and bull sharks Carcharhinus leucas (Pardini et al. 2001, Carlisle et al. 2015, Espinoza et al. 2016). Therefore, a Kendall's tau correlation test was used to investigate whether a relationship existed between body size (length) and maximum displacement distance. We further investigated whether sex-based differences existed in maximum displacement distance using a Wilcoxon test.

\subsection{Kernel density estimation}

KDE with barriers was used to describe the distribution and density of basking shark satellite tracking data occurring within the territorial waters of the IoM (12 nmi). KDE with barriers (Macleod 2014) calculates the density of features and takes into account barriers such as land (Sprogis et al. 2016). This approach was applied to location data from 5 basking sharks that spent $\geq 10 \mathrm{~d}$ in the region following tagging. Data from these individuals were interpolated to $12 \mathrm{~h}$ frequency using the adehabitatLT package in $\mathrm{R}$ and subsequently subjected to kernel analysis.

Public sightings data occurring within $12 \mathrm{nmi}$ of the IoM were also subject to KDE with barriers (Macleod 2014). The output cell size for KDEs of satellite tag data and public sightings was $100 \times 100 \mathrm{~m}$, with a bandwidth (search radius) of $5000 \mathrm{~m}$. The bandwidth permits smoothing of the kernel and can be influenced by study goals, sample size and patterns of spatial use by the study species (Gitzen et al. 2006). Accordingly, the bandwidth value was chosen via an iterative process seeking to achieve an output that was neither over smoothed, nor represented a fragmented and non-continuous density surface akin to the raw location data. Percentile spatial density was then calculated from the maximum value of KDEs with barriers.

\subsection{Movements}

Sharks were assigned to 3 non-mutually exclusive movement patterns based on their dominant temporal movement characteristics. Three categories were determined: (1) sharks that were resident to the territorial waters of the IoM for at least $10 \mathrm{~d}$ following tag- ging (I); (2) sharks moving to Scotland and the proposed Sea of the Hebrides MPA for basking sharks and minke whales (S), and (3) sharks that made farreaching movements across the North-East Atlantic (>1000 km maximum displacement; F).

\subsection{Inter-annual site fidelity}

We investigated summer inter-annual site fidelity for 4 sharks that returned to the territorial waters of the IoM in the year following tag attachment. For the first year of tagging, we calculated the geographic mean for each shark from available location data occurring within the territorial waters of the IoM; we then repeated this process for location data gathered in the following year for the same region. The distance $(\mathrm{km})$ between these geographic means was measured. This approach was also adopted for a fifth shark that exhibited inter-annual site fidelity during the northern hemisphere winter off the coast of Morocco.

\subsection{Public sightings data}

Public sightings data from recreational sea-users, land-based surveys and land-based chance sightings were collected for basking sharks seen in IoM waters by MBSW from the years 2005 to 2017. Data were analysed to provide complementary information on the distribution of basking sharks independent of tagging data. The period May to August represents the key historic sightings period for basking sharks and concurs with the months of satellite tag deployment (Witt et al. 2012). For this reason, data collected during these months were retained and subject to rigorous inspection and cleaning prior to analysis to remove locations on land, resulting in 3902 records of single or multiple sharks (representing $95 \%$ of the total public sightings data set).

\subsection{Contextual spatial data}

Shark satellite tracking data were contextualized with spatial data sets on human activity occurring within the Irish Sea that may have the potential to cause disturbance or directly impact basking sharks through contact with vessels or bycatch. Automatic Identification System (AIS; https://data.gov.uk/data set/963c1a 7 b-5b72-4cce-93f5-3f1e223fd575/ anonymised-ais-derived-track-lines-2015) data from a variety of vessel types (non-port service vessels, 
port service craft, vessels engaged in dredging or underwater operations, high-speed craft, military or law enforcement, passenger, cargo, tankers, fishing vessels, recreational vessels and unknown vessels) were extracted for 2015 and were used to provide an overview of vessel activity. AIS vessel track data (all vessels) were subject to KDE without barriers and gridded with an output cell size of $250 \times 250 \mathrm{~m}$ and a smoothing bandwidth (search radius) of $10000 \mathrm{~m}$. Fishing vessel distribution data for the Irish Sea were obtained for 2009 (http://data.marine.ie) and included gill netting, Scottish seines, beam trawls, uncategorised fishing effort and otter trawls. Fishing data for the region, originally available as raster data, were converted to point data and subjected to KDE analysis using the same parameters as AIS vessel analysis. Information on offshore winds farm was obtained from the Crown Estate (https://www.thecrownestate.co.uk). Seabed cable routes, ferry routes and hydrocarbon exploration sites were also sourced and mapped (EMODNet). Boundaries of IoM MNRs were obtained from the Isle of Man Government (2017), bathymetric data (rasters and contours) were extracted from GEBCO (www.gebco.net) and boundaries describing the Economic Exclusive Zone (EEZ) (www. marineregions.org) were also sourced.

\section{RESULTS}

\subsection{Satellite tracking}

Basking sharks $(\mathrm{n}=11)$ were tagged with SPOT tags in June, July and August between 2013 and 2017 (excluding 2014) along the western coastal region of the IoM. Basking sharks were tracked for a median of $378 \mathrm{~d}$ (interquartile range [IQR]: 227-424; range: 89-804), moved a median minimum straightline distance of $541 \mathrm{~km}$ (IQR: 353-1420; range: 170-10406 km) and displaced from their tagging locations a median maximum straight-line distance of $329 \mathrm{~km}$ (IQR: 169-347; range: 36-2783 km) (for individual trajectories, see Fig. S1). There was a significant positive correlation between minimum straight-line distance moved and tracking duration (Kendall's rank correlation $T=47$, tau $=0.71, \mathrm{p}=$ $0.002, \mathrm{n}=11$ ). There was no significant correlation between body length and maximum displacement distance (Kendall's rank correlation $z=1.2751$; tau $=$ $0.33, \mathrm{p}=0.2023, \mathrm{n}=11$ ) or sex and maximum displacement distance (Wilcox rank sum test $\mathrm{W}=9.5$, $\mathrm{p}=0.68, \mathrm{n}=11$ ).
Sharks were assigned to 3 non-mutually exclusive movement patterns based on (1) extended occupancy of the territorial waters of the IoM $(\geq 10 \mathrm{~d})$, (2) summer northward movements to Scotland and (3) undertaking far-ranging movements across the North-East Atlantic Ocean. Of the tracked cohort, 5 sharks (128185, 129180, 129181, 129184 and 138609) exhibited residency to the territorial waters of the IoM (Table 1, 'I'), 5 sharks undertook movements to the coastal waters of Scotland (129182, $129183,129184,129185$ and 161267); 3 of the latter 5 sharks occupied the Sea of the Hebrides proposed MPA (Table 1, 'S'; 129182, 129183 and 161267) and 2 sharks undertook far-ranging movements in the North-East Atlantic (Table 1, ' $F^{\prime}$; 138610, 161266). A single shark could not be assigned a movement pattern as no locations were received between the date of tagging and the incidental capture of the animal $132 \mathrm{~d}$ later in the Celtic Sea, $345 \mathrm{~km}$ south of the tagging location $\left(51.11^{\circ} \mathrm{N}, 6.37^{\circ} \mathrm{W}\right.$; Table 1 , 161289).

Three of the 11 satellite tags attached to basking sharks detached from their study animals in the Irish Sea, when 2 sharks were east of Drogheda (Republic of Ireland; 129181, 129183) and when one shark was $12 \mathrm{~km}$ north of the IoM (129180). One tag (129184) attached to a basking shark detached near Rathlin Island (Northern Ireland), a further tag detached $110 \mathrm{~km}$ northwest of Malin Head, Republic of Ireland (138609), 2 tags detached in Scottish waters $(129185,161267)$, one in the Bristol Channel, UK (129182), one $500 \mathrm{~km}$ west of Lisbon, Portugal (138610), and one $125 \mathrm{~km}$ north west of Trondheim, Norway (161266). The resulting pattern of tag detachment locations revealed the geographic range over which these animals moved and provided important tracking end-points, often revealed from locations where animals did not display prolonged surfacing behaviour.

\subsection{Isle of Man coastal occupancy}

Satellite tags attached to 5 sharks revealed occupancy ( $\geq 10 \mathrm{~d}$ ) of IoM territorial waters following tagging. These individuals almost exclusively occupied waters within the $3 \mathrm{nmi}$ fisheries zone for 11$29 \mathrm{~d}$ at the surface, remaining to the west of the IoM (Fig. 1). One shark (129180), in the year subsequent to tagging, used waters out to the $12 \mathrm{nmi}$ territorial limit (Fig. 1B). Following occupancy of IoM waters, tagged basking sharks made northerly, westerly and southerly movements (Fig. 1). 

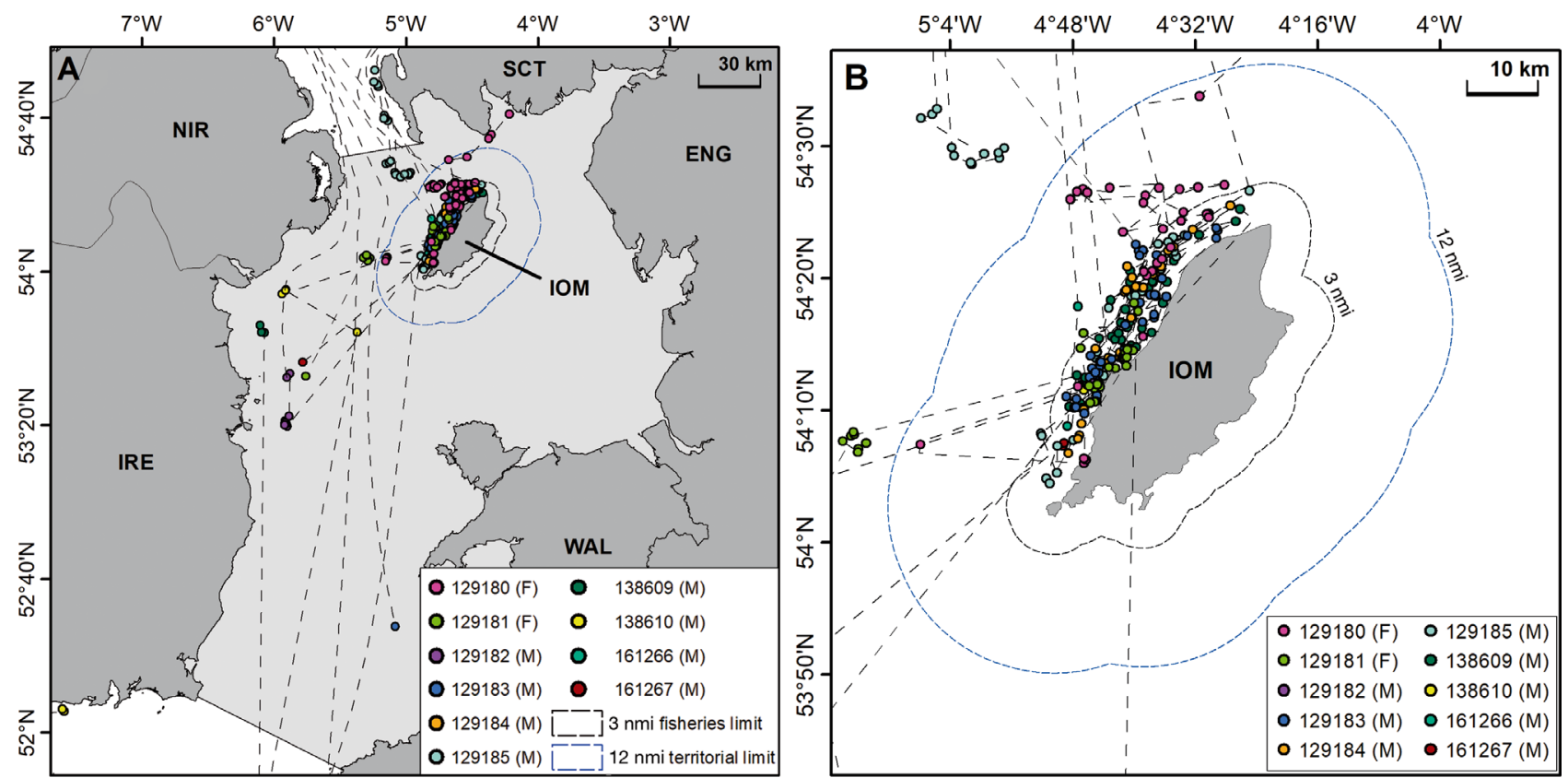

Fig. 1. Coastal movements of 10 satellite tracked basking sharks. (A) Basking shark location data (coloured points; sex of shark indicated) within the Irish Sea (light grey polygon) and (B) tracking data showing distribution in territorial waters of the Isle of Man. Satellite tracks (inferred, not actual movement) are indicated by dashed lines. nmi: nautical miles

\subsection{Seasonal northward movements}

Five sharks undertook seasonal northerly movements from the IoM (Fig. 2), spending time in coastal waters to the west of Scotland. Two of these sharks remained in the Clyde Sea (129184 and 129185) before their satellite tags detached, and 3 sharks (129182, 129183 and 161267) moved into the Inner Hebrides and the proposed Sea of the Hebrides proposed MPA (Fig. 2). Two of these individuals were tracked for 5 and $39 \mathrm{~d}$ in the proposed MPA, respectively. Location data from the third individual were intermittent and sparse, preventing a calculation of occupancy within the region. These movements demonstrated the interconnectivity of basking sharks tagged in IoM waters to other proposed conservation zones and areas of regional importance.

\subsection{Far-ranging movements}

Two tagged basking sharks travelled into international waters (Fig. 3). One shark (138610) visited 5 EEZs, including those of the UK, Ireland, France, Portugal and Morocco, and also waters beyond national jurisdictions. This individual travelled from the IoM in the summer of 2015 to Morocco in the winter of 2015/ 2016. In the spring of 2016, the shark appeared in the Bay of Biscay and southern Ireland and reappeared again near Malin Head, Ireland, in the summer. Dur- ing January 2017, the shark appeared off the coast of Portugal and Morocco and reappeared during November 2017 off the coast of Portugal, where the tag detached (804 d after deployment). This is the first documented multi-year tracking $(>2 \mathrm{yr}$ ) of a tagged basking shark. A second tagged shark (tag 161266) passed through 5 EEZs - the UK, Faeroe, French, Spanish and Norwegian EEZs - as well as occupying areas outside EEZ boundaries. The shark travelled from the IoM in the summer of 2016 to the Faroe Islands 2 mo later. This shark then re-appeared $1131 \mathrm{~km}$ west of the coast of France before travelling to the Bay of Biscay in March and remaining there until April 2017. The final location of this shark occurred off Norway 485 d later in October 2017, when the tag detached. This is the first instance of a basking shark being tracked into Norwegian waters.

\subsection{Satellite tracking and public sightings data}

KDE analysis of basking shark satellite tracking data occurring within territorial waters of the IoM (129181, 129183, 129184, 129185 and 138609) highlighted areas of high relative density extending along the western coastline, from Point of Ayre to The Sound (Fig. 4A). Core regions of basking shark distribution (KDE $50 \%$ density) occurred predominantly within $3 \mathrm{nmi}$ west of the IoM with sections occurring within the West Coast MNR (Fig. 4A). Regions of basking 


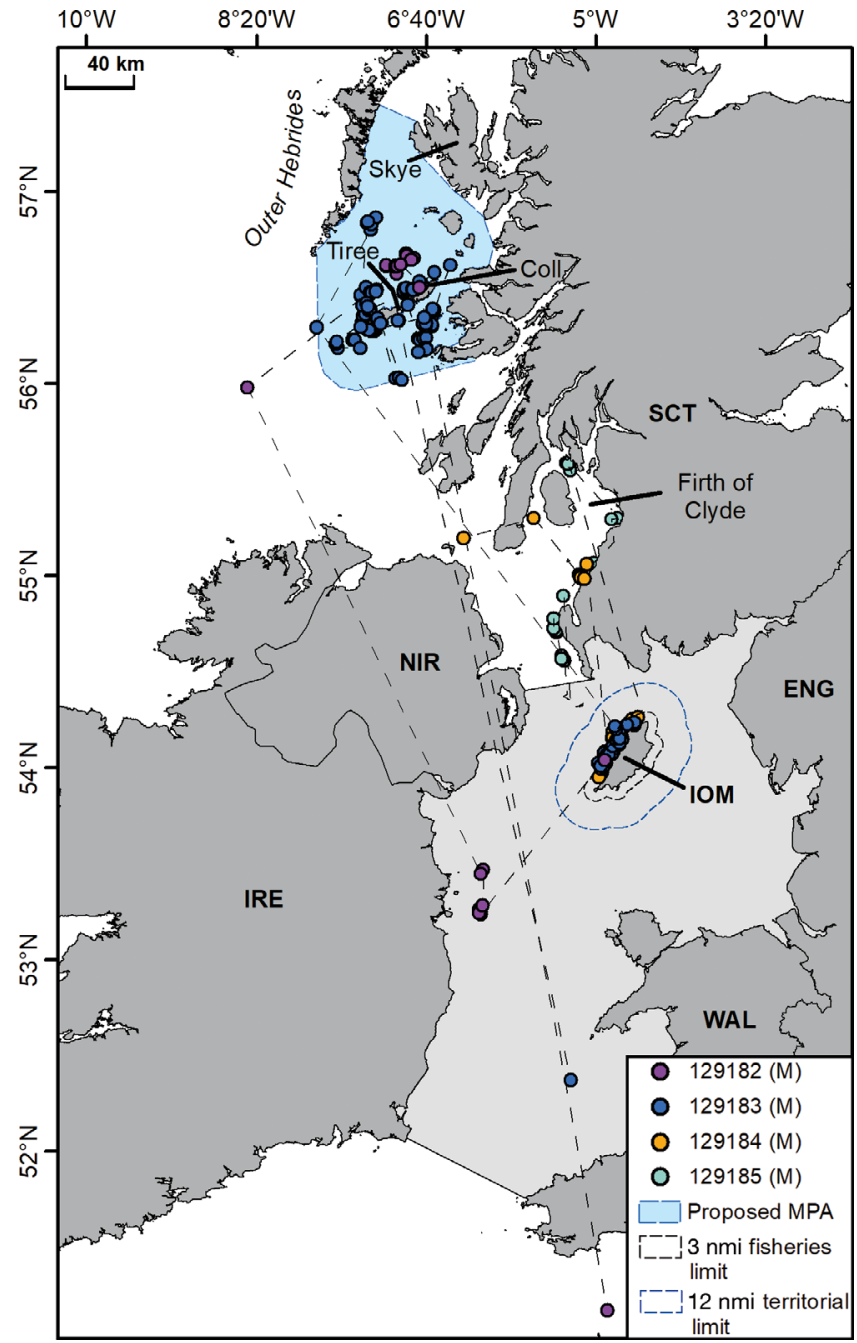

Fig. 2. Seasonal northward movements of 4 satellite tracked basking sharks. Light grey polygon denotes the Irish Sea and the light blue polygon displays the proposed Sea of the Hebrides Marine Protected Area. Sharks moved to the

Clyde Sea and Sea of the Hebrides. nmi: nautical miles

shark distribution outside the core area (KDE > $50 \%$ ) bordered the core area, extending in westerly, southwesterly and northwesterly directions into the $12 \mathrm{nmi}$ territorial limit. These regions overlapped the West Coast MNR, Niarbyl Bay MNR and Port Erin Bay MNR, located within the $3 \mathrm{nmi}$ limit (Fig. 4A).

$\mathrm{KDE}$ of public sightings data revealed similar patterns to the satellite tracking data (Fig. 4B). Core distribution areas (KDE $50 \%$ ) occurred within $3 \mathrm{nmi}$ of the west coast and southwest coast, extending around the Calf of Man, into the West Coast MNR and Calf and Wart Bank MNR, Niarbyl Bay MNR, Port Erin Bay MNR and Baie ny Carrickey MNR. Data outside the core regions of basking shark distribution $(>50 \% \mathrm{KDE})$ followed the same pattern mostly within the $3 \mathrm{nmi}$ limit with $95 \% \mathrm{KDE}$, extend-

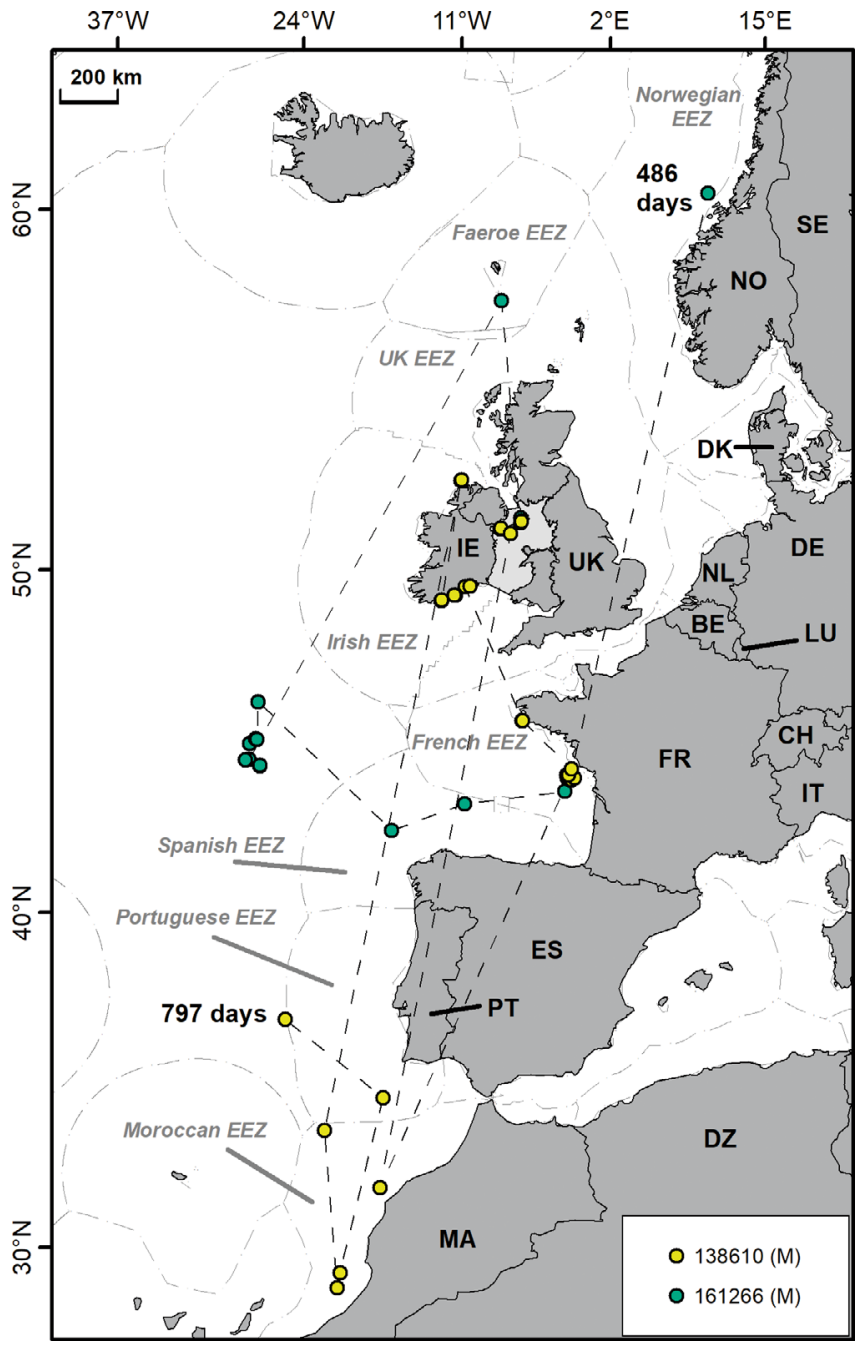

Fig. 3. Far-ranging movements of 2 satellite tracked basking sharks. Maximum displacement locations of sharks tagged in Isle of Man coastal waters (138610 and 161266) were Morocco and Norway, respectively. Dashed grey lines indicate Exclusive Economic Zone (EEZ) boundaries and the light grey polygon denotes the Irish Sea

ing this pattern westerly into the $12 \mathrm{nmi}$ limit and southerly within the $3 \mathrm{nmi}$ limit around the Calf of Man and into Langness MNR.

Analysis of filtered basking shark satellite tracking locations occurring within the territorial seas of the IoM revealed that $59 \pm 35 \%$ of location data (mean \pm $\mathrm{SD} ; \mathrm{n}=11$ tracked basking sharks) and $58 \%$ of public sightings data (of single or multiple sharks) were located within MNRs. If the West Coast MNR was extended to the $3 \mathrm{nmi}$ boundary throughout its range, $77 \pm 32 \%$ of satellite location data and an additional $3 \%$ of public sightings data would occur within the modified boundary. The MNRs were not designed based on access to these public sightings or satellite tracking data. 


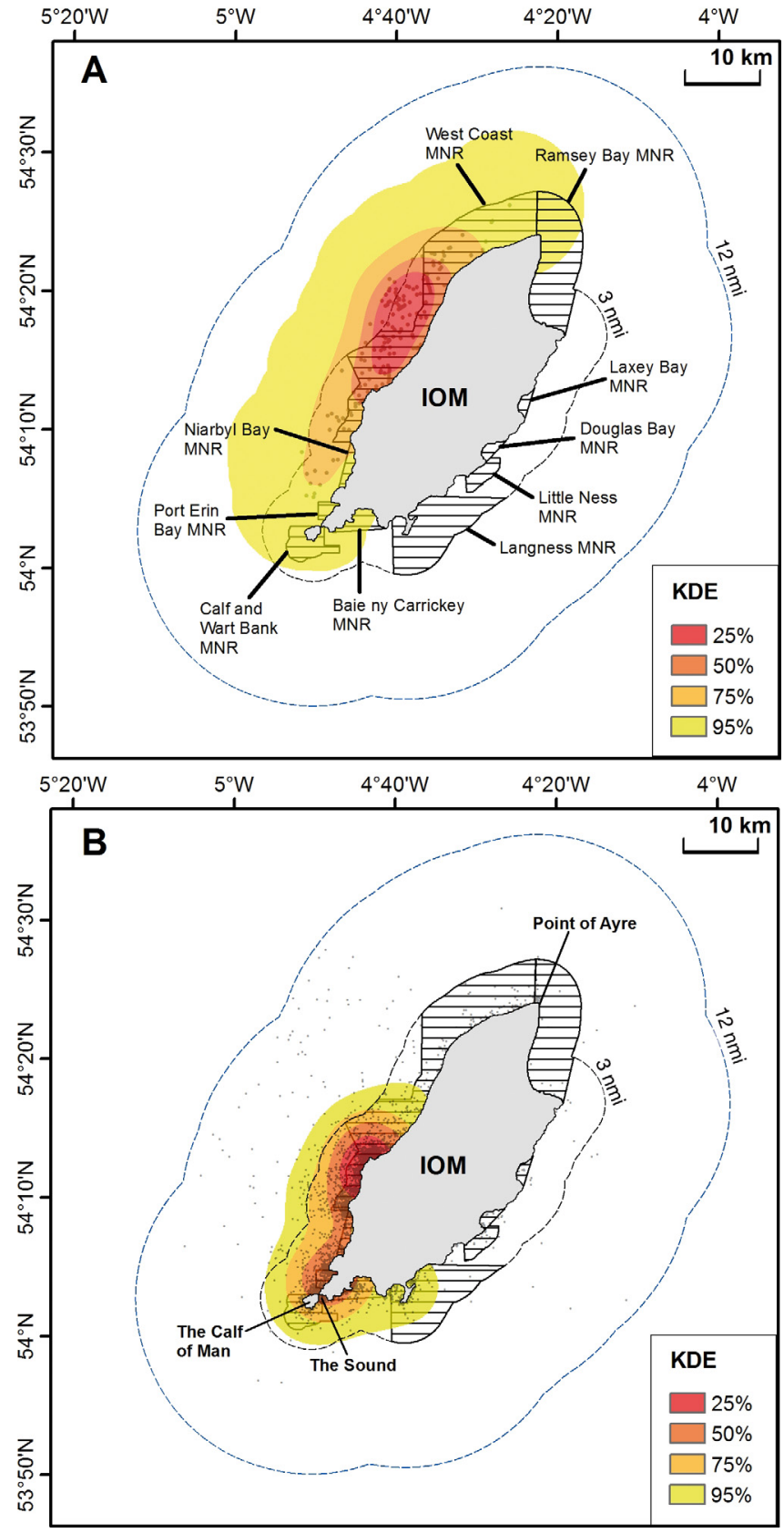

Fig. 4. Density of basking shark satellite tracking and public sightings data. Kernel density interpolation with barriers of (A) satellite tag data and (B) public sightings data smoothed to $5 \mathrm{~km}$. Both maps display Marine Nature Reserves (MNRs). Pale black dots indicate data points used during kernel density estimation (KDE)

\subsection{Inter-annual site fidelity}

Four basking sharks returned to the Irish Sea in the year after tagging, demonstrating inter-annual site fidelity (Fig. 5). The sharks returned within 371, 352, 397 and 298 d (sharks 129180, 129183, 129185, and 138609, respectively), with the distance between the mean geographic locations of year 1 and year 2 data being 39, 196, 35 and $105 \mathrm{~km}$ apart (Fig. 5A-D). One shark displayed site fidelity to the Moroccan EEZ, $346 \mathrm{~d}$ later during northern hemisphere winters in 2016 and 2017, with a separation between the annual geographic mean locations of 430 km (Fig. 5E).

\subsection{Anthropogenic threats}

Across the seascape through which the tagged sharks occurred, multiple human pressures were present. Areas of high relative vessel presence $\left(>46\right.$ AIS vessel density per $2 \mathrm{~km}^{2}$ ) could be seen near Liverpool, Belfast, Dublin and Portpatrick Harbours. Vessel activity ( $>46$ AIS vessel density per $2 \mathrm{~km}^{2}$ ) in the Irish Sea occurred along 3 main routes into the Irish Sea from the Celtic Sea, from Liverpool to Dublin, the south and west coasts of the IoM, west of Heysham and from Dublin to the North Channel located between Northern Ireland and Scotland (Fig. 6B). Kernel density analysis of fishing activity in the Irish Sea indicated a relatively small area of gill net fisheries east of Drogheda, Ireland; Scottish seine fisheries extending from Dublin to the south coast of the IoM; beam trawls off the east coast of Ireland and off Liverpool to Heysham, UK; and otter trawl activity to the east of Drogheda to Dublin and west of the Lake District, UK (Fig. 6B). 'Uncategorised' fishing occurred widely across the Irish Sea, and although the direct threat to basking sharks cannot be assessed, it further demonstrates occurrence of the species with human activities at sea. Seabed cables run across the Irish Sea and to the east of the IoM from wind farms. Within $12 \mathrm{nmi}$ of the IoM, there is a proposed wind farm development site and hydrocarbon exploration site (Fig. 6A).

\section{DISCUSSION}

This study demonstrates the importance of the waters of the IoM for basking shark populations locally, regionally and internationally. Our data revealed local IoM hotspots, interconnectivity between the IoM and a proposed MPA for basking sharks west of Scotland, inter-annual site fidelity to the Irish Sea, and, for the first time, movements to Norway and overwintering site fidelity to Moroccan waters. 

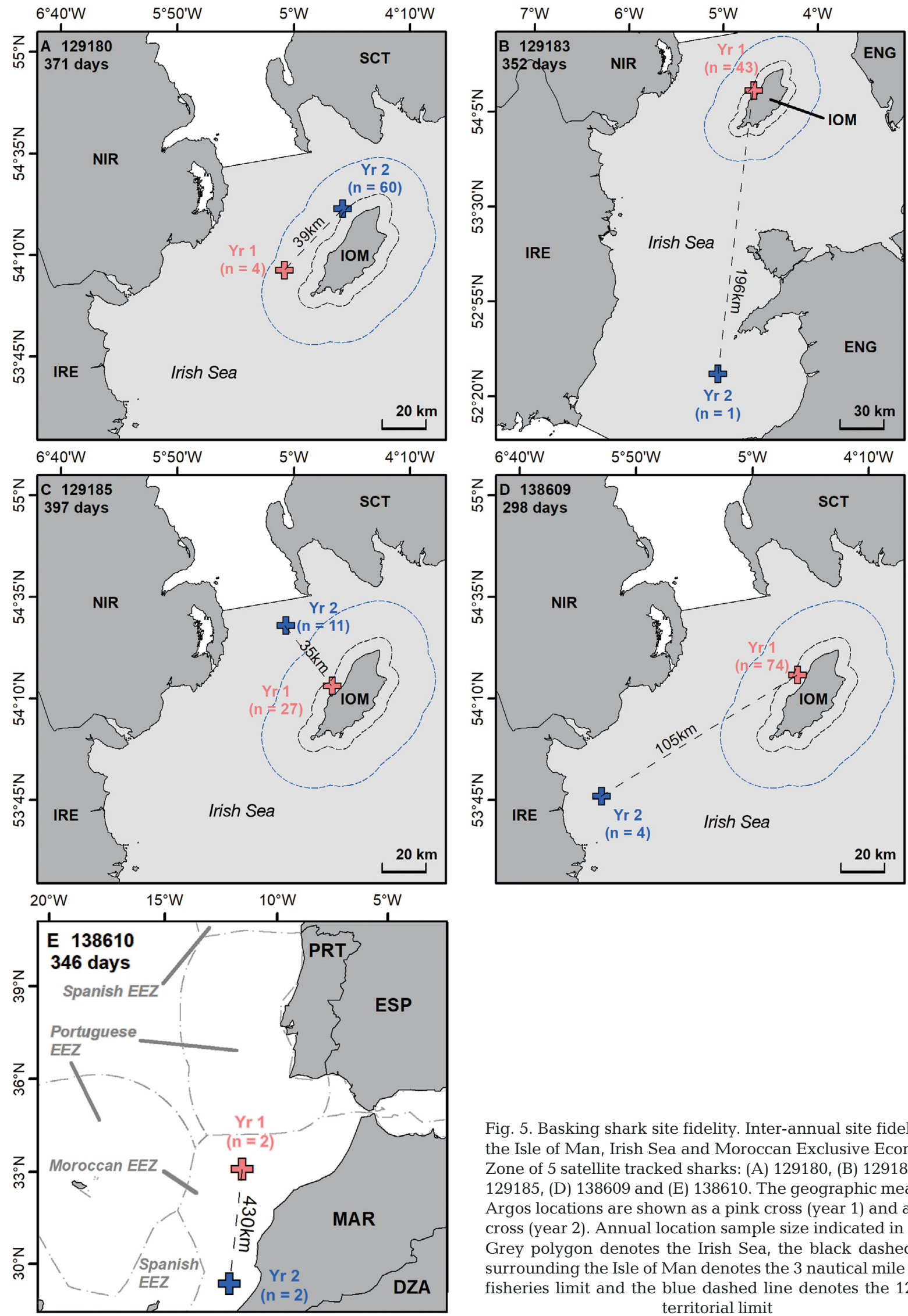

Fig. 5. Basking shark site fidelity. Inter-annual site fidelity to the Isle of Man, Irish Sea and Moroccan Exclusive Economic Zone of 5 satellite tracked sharks: (A) 129180, (B) 129183, (C) 129185, (D) 138609 and (E) 138610. The geographic means of Argos locations are shown as a pink cross (year 1) and a blue cross (year 2). Annual location sample size indicated in plots. Grey polygon denotes the Irish Sea, the black dashed line surrounding the Isle of Man denotes the 3 nautical mile (nmi) fisheries limit and the blue dashed line denotes the $12 \mathrm{nmi}$ territorial limit 

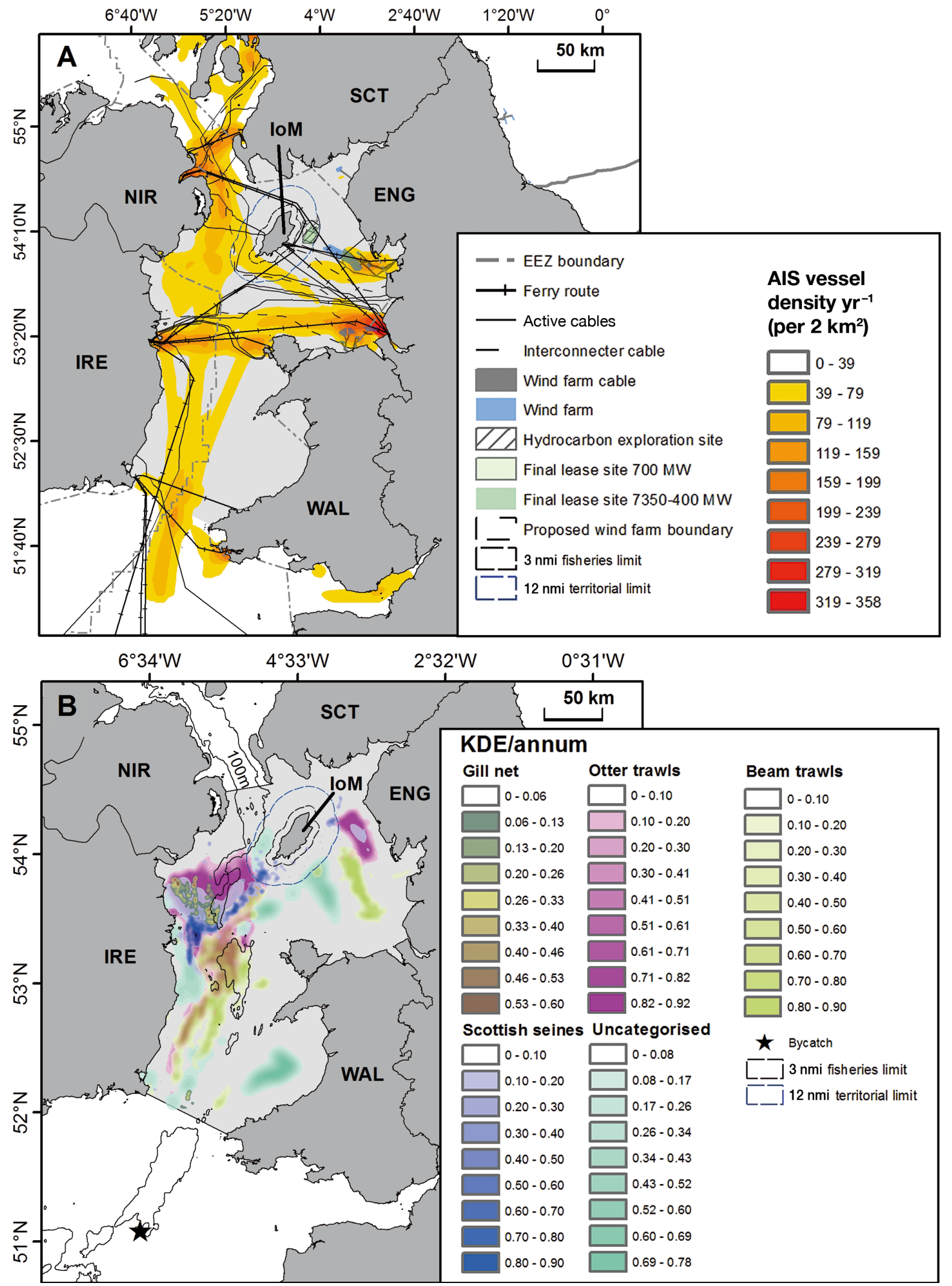

Fig. 6. Putative anthropogenic threats. (A) Fixed anthropogenic threats within the Irish Sea, including 2015 Automatic Identification System (AIS) vessel data smoothed to $10 \mathrm{~km}$. (B) Mobile fishing activity occurring in 2009 within the Irish Sea, smoothed to $10 \mathrm{~km}$. Light grey polygon denotes the Irish Sea. EEZ: Exclusive Economic Zone; nmi: nautical miles 


\subsection{Satellite tagging technology and public sightings data}

Satellite tracking and public sightings data reveal that basking sharks are predominantly found in western IoM waters, generally within $3 \mathrm{nmi}$ of the shore. Basking sharks tagged in IoM waters exhibit a variety of movement patterns, with some remaining for extended periods in IoM waters and the Irish Sea during the summer, while others move to the Sea of Hebrides in Scotland, and more ( 2 in the present study) making long-distance movements crossing international boundaries, travelling approximately $10000 \mathrm{~km}$ (in $2.2 \mathrm{yr}$ ) and $6000 \mathrm{~km}$ (in $1.3 \mathrm{yr}$ ) to waters off Morocco and Norway, respectively. In addition, we show that public sightings data can be used to support basking shark tracking data in the IoM (Southall et al. 2005, Witt et al. 2012), but also may reveal subtly different patterns of spatial distribution in IoM waters.

This variation underscores the importance of understanding shark temporal and spatial movements in developing conservation plans for basking sharks. Satellite tagging studies have revealed details of migration, diving behaviours, site fidelity, and depth and temperature preferences of sharks and rays (Rowat et al. 2007, Bonfil et al. 2010, Graham et al. 2012, Doherty et al. 2017b, Vaudo et al. 2017, Rohner et al. 2018). For example, basking sharks were previously thought to hibernate during the northern hemisphere winter; however, satellite tagging of a limited number of basking sharks at the time suggested that instead they utilise productive habitats during the summer, autumn and winter (Sims et al. 2003). More recent studies of basking sharks in Scotland have revealed 3 main migration strategies, including their spatial use within the proposed Sea of the Hebrides MPA (Doherty et al. 2017a), and provided evidence of shared foraging sites in Scotland (Doherty et al. 2017b). The present study has provided new insights into basking shark spatial distribution within IoM waters and beyond. Future tagging studies are needed to establish main migration routes of all basking shark populations to inform cohesive, legally binding, international conservation agreements between signatories.

\subsection{Inter-annual site fidelity}

Site fidelity is observed in many shark and ray species (Graham et al. 2012, Chapman et al. 2015) and may be indicative of nursery areas (Heupel et al. 2007). Site fidelity of basking sharks was not well described until recently, for waters off the west coast of Scotland (Doherty et al. 2017b). Here, we have demonstrated inter-annual site fidelity by 5 basking sharks to the Irish Sea, and IoM waters specifically, and 1 to the Moroccan EEZ, overwintering there in 2 concurrent years. This further highlights the importance of protecting IoM waters as a key part of the internationally connected habitats in which basking shark populations occur.

\subsection{Anthropogenic threats}

Human use of the oceans is increasing both globally and within the North-East Atlantic (Halpern et al. 2008). Of concern to basking sharks and the potential for strike risk and disturbance are the threats associated with maritime passages, such as shipping lanes. The risk of vessel strike has been well documented for cetaceans (Van Waerebeek et al. 2007, BermanKowalewski et al. 2010, Tricas \& Gill 2011, Halvorsen et al. 2012) but not yet quantified for basking sharks (for an overview, see Pirotta et al. 2019; for examples of dorsal fin damage from supposed vessel collisions, see Sims et al. 2000b, Hall et al. 2013). Results of the present study could be used to mitigate threat by identifying areas of high-risk activities and subsequent areas of co-occurrence, allowing decision makers to place sensible management measures on developments (e.g. time-of-day speed restrictions) or impose speed restrictions or re-route maritime passages (Pirotta et al. 2019). To ensure effective protection of basking sharks in IoM waters, seasonal speed restrictions (Speedie et al. 2009) or re-routing vessel traffic to avoid basking shark hotspots could be considered (Irvine et al. 2014). Although dedicated fisheries for basking sharks have ceased in European waters, basking sharks are indirectly threatened from bycatch (Berrow 1994, Berrow \& Heardman 1994, Francis \& Duffy 2002). One shark in our study was bycaught in the Celtic Deep, Wales, and at least 7 basking sharks have been previously bycaught in the Celtic Sea between 2001 and 2007 (Stéphan et al. 2011). Basking sharks in the present study overlapped with the distribution of high-risk fisheries such as set gill net fisheries (surface and seabed). Fisheries data for IoM waters were not available for analysis in this study, although should they become available, they would help to provide a cohesive overview of human activity throughout the Irish Sea including the coastal waters of the IoM. Assessing the true scale of the risk of bycatch by commercial fisheries is a priority for basking shark conservation. 
Important behaviours thought to be associated with courtship (including nose-to-tail following and breaching; Harvey-Clark et al. 1999, Sims et al. 2000a) have been observed in the IoM (Hall et al. 2013). There has also been one documented case of putative mating observed in IoM waters (Waller 2000). Therefore, the waters of the IoM may potentially host breeding basking sharks. This further highlights the potential importance of IoM waters for the species.

This study also confirms findings in other studies (e.g. Dewar et al. 2018) that some basking sharks spend time outside EEZs and are potentially vulnerable to fisheries bycatch in these areas where protection is limited. The area outside EEZs in this study is within the North East Atlantic Fisheries Commission (NEAFC) and the Convention on Future Multilateral Cooperation in the North-East Atlantic Fisheries and is subject to a ban on directed fisheries for basking sharks during 2016-2019 (NEAFC 2016). Continued research is required to quantify the risks associated with migration into regions beyond national jurisdiction.

\subsection{MPA space use}

MPAs may be a useful means with which to protect mobile marine species (Worm et al. 2003) if the target species occupy them for extended periods during key life history stages (such as breeding or feeding) (Hooker \& Gerber 2004, Speed et al. 2011, Escalle et al. 2015, Lea et al. 2016). MPAs should be designed around robust spatial data, increasing their potential to conserve species (Doherty et al. 2017b). In the present study, $59 \%$ of satellite tagging data and $58 \%$ of public sightings location data were within IoM MNRs. Such data could be used to modify appropriate MNRs in IoM waters based on basking shark spatio-temporal abundance, for example, extending the western boundary of the West Coast MNR to the 3 nmi fisheries limit would include $\sim 20 \%$ more satellite tracking location data. Management plans for the new MNRs are currently under development and the results from this study could inform decision making within the reserves.

\subsection{Future improvements}

Despite the annual appearance of basking sharks in IoM waters, it is not yet clear which of their key life history events take place in the region. Greater insights could be achieved using a multi-sensor biologging approach (Hammerschlag et al. 2011, Fontes et al. 2017), e.g. using accelerometers, genetic analysis and animal-towed cameras (Fontes et al. 2017, Riekkola et al. 2018). In addition, survey drones could provide a new perspective on basking shark aggregations, which may be linked to breeding (Crowe et al. 2018). Additionally, assessing basking shark ship-strike risk could be achieved by comparing animal location data and marine traffic data to identify potential high-risk zones (Hazen et al. 2017) and impose adaptive management strategies such as seasonal management areas (Pirotta et al. 2019).

\subsection{Conclusions}

The present study demonstrates the importance of the IoM to basking sharks at local, regional and international scales, and defines hotspots of occurrence of basking sharks around the IoM as well as interannual site fidelity to IoM waters. This study reveals that new MNRs circumscribed half of basking shark satellite tracking location data and that tracking has the potential to inform future designation and management of current and future MNRs for basking sharks. We reveal that some individuals undergo long-distance movements to Norway and Morocco and may return to these waters between years. Satellite tagging data can be complemented with public sightings of basking sharks to provide informative insights about these internationally important sharks.

Acknowledgements. We extend our sincere thanks to the many Manx Basking Shark Watch (MBSW) volunteers, who worked with us on this project since 2005. The SPOT tagging project would have been impossible without these volunteers. We particularly thank the public who shared their basking shark sightings with MBSW. The support of the Manx Wildlife Trust was much appreciated. The MBSW SPOT tagging project has been financially supported by the Manx Lottery Trust, the Department of Environment, Food and Agriculture, DONG Energy and by many local Manx businesses. Licences to tag basking sharks in IoM waters were issued by the Department of Environment, Food and Agriculture under the ManxWildlife Act, 1990. M.J.W. and L.A.H. receive funding from Scottish Natural Heritage to undertake research on basking sharks

\section{LITERATURE CITED}

Angulo-Valdés JA, Hatcher BG (2010) A new typology of benefits derived from marine protected areas. Mar Policy 34:635-644

Austin R, Hawkes LA, Doherty PD, Henderson SM and others (2019) Predicting the habitat suitability for basking 
sharks in UK waters using ensemble ecological niche modelling. J Sea Res 153:101767

Berman-Kowalewski M, Gulland FMD, Wilkin S, Calambokidis $\mathrm{J}$ and others (2010) Association between blue whale (Balaenoptera musculus) mortality and ship strikes along the California coast. Aquat Mamm 36:59-66

Berrow SD (1994) Incidental capture of elasmobranchs in the bottom-set gill-net fishery off the south coast of Ireland. J Mar Biol Assoc UK 74:837-847

Berrow SD, Heardman C (1994) The basking shark Cetorhinus maximus (Gunnerus) in Irish waters - patterns of distribution and abundance. Biol Environ 2:101-107

Bivand R, Keitt T, Rowlingson B, Pebesma E and others (2018) Package 'rgdal'. R-CRAN Version 1.3-4. https:// CRAN.R-project.org/package $=$ rgdal

Blower DC, Pandolfi JM, Bruce BD, Gomez-Cabrera MdC, Ovenden JR (2012) Population genetics of Australian white sharks reveals fine-scale spatial structure, transoceanic dispersal events and low effective population sizes. Mar Ecol Prog Ser 455:229-244

Bonfil R, Francis MP, Duffy C, Manning MJ, O'Brien S (2010) Large-scale tropical movements and diving behavior of white sharks Carcharodon carcharias tagged off New Zealand. Aquat Biol 8:115-123

Carlisle AB, Goldman KJ, Litvin SY, Madigan DJ and others (2015) Stable isotope analysis of vertebrae reveals ontogenetic changes in habitat in an endothermic pelagic shark. Proc Biol Sci 282:20141446

Chapman DD, Feldheim KA, Papastamatiou YP, Hueter RE (2015) There and back again: a review of residency and return migrations in sharks, with implications for population structure and management. Annu Rev Mar Sci 7: 547-570

Clarke S, Milner-Gulland EJ, Bjørndal T (2007) Social, economic, and regulatory drivers of the shark fin trade. Mar Resour Econ 22:305-327

* Coyne MS, Godley BJ (2005) Satellite Tracking and Analysis Tool (STAT): an integrated system for archiving, analyzing and mapping animal tracking data. Mar Ecol Prog Ser 301:1-7

* Crowe LM, O'Brien O, Curtis TH, Leiter SM, Kenney RD, Duley P, Kraus SD (2018) Characterization of large basking shark Cetorhinus maximus aggregations in the western North Atlantic Ocean. J Fish Biol 92:1371-1384

* Dewar H, Wilson SG, Hyde JR, Snodgrass OE and others (2018) Basking shark (Cetorhinus maximus) movements in the Eastern North Pacific determined using satellite telemetry. Front Mar Sci 5:163

Doherty PD, Baxter JM, Gell FR, Godley BJ and others (2017a) Long-term satellite tracking reveals variable seasonal migration strategies of basking sharks in the northeast Atlantic. Sci Rep 7:42837

* Doherty PD, Baxter JM, Godley BJ, Graham RT and others (2017b) Testing the boundaries: seasonal residency and inter-annual site fidelity of basking sharks in a proposed Marine Protected Area. Biol Conserv 209:68-75

*DDulvy NK, Fowler SL, Musick JA, Cavanagh RD and others (2014) Extinction risk and conservation of the world's sharks and rays. eLife 3:e00590

* Escalle L, Speed CW, Meekan MG, White WT, Babcock RC, Pillans RD, Huveneers C (2015) Restricted movements and mangrove dependency of the nervous shark Carcharhinus cautus in nearshore coastal waters. J Fish Biol 87: 323-341

Espinoza M, Heupel MR, Tobin AJ, Simpfendorfer CA
(2016) Evidence of partial migration in a large coastal predator: opportunistic foraging and reproduction as key drivers? PLOS ONE 11:e0147608

Fontes J, Baeyaert J, Prieto R, Graça G and others (2017) New non-invasive methods for short-term electronic tagging of pelagic sharks and rays. Mar Biol 165:2-3

Fossette S, Witt MJ, Miller P, Nalovic MA and others (2014) Pan-Atlantic analysis of the overlap of a highly migratory species, the leatherback turtle, with pelagic longline fisheries. Proc Biol Sci 281:20133065

Fossi MC, Coppola D, Baini M, Giannetti M and others (2014) Large filter feeding marine organisms as indicators of microplastic in the pelagic environment: the case studies of the Mediterranean basking shark (Cetorhinus maximus) and fin whale (Balaenoptera physalus). Mar Environ Res 100:17-24

Francis M, Duffy C (2002) Distribution, seasonal abundance and bycatch of basking sharks (Cetorhinus maximus) in New Zealand, with observations on their winter habitat. Mar Biol 140:831-842

Freitas C (2012) Package 'argosfilter . R-CRAN Version 0.63. https://CRAN.R-project.org/web/packages/argosfilter/ argosfilter.pdf

* Gitzen RA, Millspaugh JJ, Kernohan BJ (2006) Bandwidth selection for fixed-kernel analysis of animal utilization distributions. J Wildl Manag 70:1334-1344

*Godley BJ, Blumenthal JM, Broderick AC, Coyne MS, Godfrey MH, Hawkes LA, Witt MJ (2008) Satellite tracking of sea turtles: Where have we been and where do we go next? Endang Species Res 4:3-22

Gore MA, Rowat D, Hall J (2008) Transatlantic migration and deep mid-ocean diving by basking shark. Biol Lett 4 : 395-398

* Graham RT, Witt MJ, Castellanos DW, Remolina F, Maxwell S, Godley BJ, Hawkes LA (2012) Satellite tracking of manta rays highlights challenges to their conservation. PLOS ONE 7:e36834

*Greene C, Block BA, Welch D, Jackson G, Lawson GL, Rechisky EL (2009) Advances in conservation oceanography: new tagging and tracking technologies and their potential for transforming the science underlying fisheries management. Oceanography 22:210-223

Hall J, Stone E, Gell F, Hanley L (2013) Basking sharks. In: Hanley LJ, Gell FG, Kennington K, Stone E and others (eds) Manx Marine Environmental Assessment. Isle of Man Marine Plan. Isle of Man Government

* Halpern BS, Walbridge S, Selkoe KA, Kappel CV and others (2008) A global map of human impact on marine ecosystems. Science 319:948-952

*Halvorsen MB, Casper BM, Woodley CM, Carlson TJ, Popper AN (2012) Threshold for onset of injury in Chinook salmon from exposure to impulsive pile driving sounds. PLOS ONE 7:e38968

*Hammerschlag N, Gallagher AJ, Lazarre DM (2011) A review of shark satellite tagging studies. J Exp Mar Biol Ecol 398:1-8

KHammerschlag N, Broderick AC, Coker JW, Coyne MS and others (2015) Evaluating the landscape of fear between apex predatory sharks and mobile sea turtles across a large dynamic seascape. Ecology 96:2117-2126

*Harvey-Clark CJ, Stobo WT, Helle E, Mattson M (1999) Putative mating behavior in basking sharks off the Nova Scotia coast. Copeia 1999:780-782

*Hawkes LA, Balachandran S, Batbayar N, Butler PJ and others (2011) The trans-Himalayan flights of bar-headed 
geese (Anser indicus). Proc Natl Acad Sci USA 108: 9516-9519

Hays GC, Ferreira LC, Sequeira AMM, Meekan MG and others (2016) Key questions in marine megafauna movement ecology. Trends Ecol Evol 31:463-475

Hays GC, Bailey H, Bograd SJ, Bowen WD and others (2019) Translating marine animal tracking data into conservation policy and management. Trends Ecol Evol 34:459-473

*Hazen EL, Palacios DM, Forney KA, Howell EA and others (2017) Whalewatch: a dynamic management tool for predicting blue whale density in the California Current. J Appl Ecol 54:1415-1428

Heupel MR, Carlson JK, Simpfendorfer CA (2007) Shark nursery areas: concepts, definition, characterization and assumptions. Mar Ecol Prog Ser 337:287-297

Hijmans RJ, Williams E, Vennes C (2017) Package geosphere. R-CRAN Version 15-7. https://CRAN.R-project. org $/$ package $=$ geosphere

Hoelzel AR, Shivji MS, Magnussen J, Francis MP (2006) Low worldwide genetic diversity in the basking shark (Cetorhinus maximus). Biol Lett 2:639-642

*Hooker S, Gerber LR (2004) Marine reserves as a tool for ecosystem-based management: the potential importance of megafauna. Bioscience 54:27-39

Hopcraft JGC, Morales JM, Beyer HL, Borner M and others (2014) Competition, predation, and migration: individual choice patterns of Serengeti migrants captured by hierarchical models. Ecol Monogr 84:355-372

Hussey NE, Kessel ST, Aarestrup K, Cooke SJ and others (2015) Aquatic animal telemetry across diverse scales: discovery, applications and relevance. Science 348: 1255642

Irvine LM, Mate BR, Winsor MH, Palacios DM, Bograd SJ, Costa DP, Bailey H (2014) Spatial and temporal occurrence of blue whales off the U.S. West Coast, with implications for management. PLOS ONE 9:e102959

Isle of Man Government (2017) Consultation on the designation of inshore Marine Nature Reserves. Department of Environment, Food and Agriculture, Isle of Man

Kays R, Crofoot MC, Jetz W, Wikelski M (2015) Terrestrial animal tracking as an eye on life and planet. Science 348: aaa 2478

Kunzlik P (1988) The basking shark. Department of Agriculture and Fisheries for Scotland, Aberdeen, UK

Lea JS, Humphries NE, Von Brandis RG, Clarke CR, Sims DW (2016) Acoustic telemetry and network analysis reveal the space use of multiple reef predators and enhance marine protected area design. Proc Biol Sci 283: 20160717

Leroy EC, Samaran F, Bonnel J, Royer JY (2016) Seasonal and diel vocalization patterns of Antarctic blue whale (Balaenoptera musculus intermedia) in the Southern Indian Ocean: a multi-year and multi-site study. PLOS ONE 11:e0163587

Macleod CD (2014) An introduction to using GIS in marine biology. Supplementary workbook four. Investigating home ranges of individual animals. Pictish Beast Publications, Glasgow

NEAFC (North-East Atlantic Fisheries Commission) (2016) Recommendation on conservation and management measures for basking shark (Cetorhinus maximus) in the NEAFC Convention Area for 2016 to 2019. Reccomendation 08. North-East Atlantic Fisheries Commission, London, UK

* Pardini AT, Jones CS, Noble LR, Kreiser B and others (2001)
Sex-biased dispersal of great white sharks. Nature 412: 139-140

Peiman KS, Birnie-Gauvin K, Midwood JD, Larsen MH and others (2017) If and when: intrinsic differences and environmental stressors influence migration in brown trout (Salmo trutta). Oecologia 184:375-384

*Pirotta V, Grech A, Jonsen ID, Laurance WF and others (2019) Consequences of global shipping traffic for marine giants. Front Ecol Environ 17:39-47

R Development Core Team (2016) R: A language and environment for statistical computing. R Foundation for Statistical Computing, Vienna

Kiekkola L, Zerbini AN, Andrews O, Andrews-Goff V and others (2018) Application of a multi-disciplinary approach to reveal population structure and Southern Ocean feeding grounds of humpback whales. Ecol Indic 89:455-465

Rigby CL, Barreto R, Carlson J, Fernando D and others (2019) Cetorhinus maximus. The IUCN Red List of Threatened Species. www.iucnredlist.org (accessed 1 February 2020)

Rohner CA, Richardson AJ, Jaine FRA, Bennett MB and others (2018) Satellite tagging highlights the importance of productive Mozambican coastal waters to the ecology and conservation of whale sharks. PeerJ 6:e4161

* Rowat D, Meekan MG, Engelhardt U, Pardigon B, Vely M (2007) Aggregations of juvenile whale sharks (Rhincodon typus) in the Gulf of Tadjoura, Djibouti. Environ Biol Fishes 80:465-472

Runge CA, Martin TG, Possingham HP, Willis SG, Fuller RA (2014) Conserving mobile species. Front Ecol Environ 12: 395-402

* Schmidt JV, Schmidt CL, Ozer F, Ernst RE, Feldheim KA, Ashley MV, Levine M (2009) Low genetic differentiation across three major ocean populations of the whale shark, Rhincodon typus. PLOS ONE 4:e4988

* Sims DW, Southall EJ, Quayle VA, Fox AM (2000a) Annual social behaviour of basking sharks associated with coastal front areas. Proc Biol Sci 267:1897-1904

* Sims DW, Speedie CD, Fox AM (2000b) Movements and growth of a female basking shark re-sighted after a three year period. J Mar Biol Assoc UK 80:1141-1142

* Sims DW, Southall EJ, Richardson AJ, Reid PC, Metcalfe JD (2003) Seasonal movements and behaviour of basking sharks from archival tagging: no evidence of winter hibernation. Mar Ecol Prog Ser 248:187-196

Kouthall EJ, Sims DW, Metcalfe JD, Doyle JI and others (2005) Spatial distribution patterns of basking sharks on the European shelf: preliminary comparison of satellitetag geolocation, survey and public sightings data. J Mar Biol Assoc UK 85:1083-1088

Speed CW, Meekan MG, Field IC, McMahon CR and others (2011) Spatial and temporal movement patterns of a multi-species coastal reef shark aggregation. Mar Ecol Prog Ser 429:261-275

Speedie C, Johnson L, Witt M (2009) Basking shark hotspots on the west coast of Scotland: key sites, threats and implications for conservation of the species. Commissioned Report No. 339, Scottish Natural Heritage, Inverness

Sprogis KR, Raudino HC, Rankin R, MacLeod CD and others (2016) Home range size of adult Indo-Pacific bottlenose dolphins (Tursiops aduncus) in a coastal and estuarine system is habitat and sex-specific. Mar Mamm Sci 32: 287-308

Stéphan E, Gadenne H, Jung A (2011) Satellite tracking of basking sharks in the North-East Atlantic Ocean. Final 
Report. Association Pour l'Etude la Conservation des Sélaciens (Non-governmental Organization for the Study Conservation of Elasmobranchs). www.asso-apecs.org/ IMG/pdf/Final_report_-_Sur_les_traces_du_requin_ pelerin_-_Feb_2011.pdf

Tricas T, Gill A (2011) Effects of EMFs from undersea power cables on elasmobranchs and other marine species. Dept. of the Interior, Bureau of Ocean Energy Management, Regulation, and Enforcement, Pacific OCS Region. US Department of the Interior, Washington, DC

Van Waerebeek K, Baker AN, Félix F, Gedamke J and others (2007) Vessel collisions with small cetaceans worldwide and with large whales in the Southern Hemisphere, an initial assessment. Lat Am J Aquat Mamm 6:43-69

Vaudo JJ, Byrne ME, Wetherbee BM, Harvey GM, Shivji MS (2017) Long-term satellite tracking reveals regionspecific movements of a large pelagic predator, the shortfin mako shark, in the western North Atlantic Ocean. J Appl Ecol 54:1765-1775

Waller J (2000) Synchronised swimmers. BBC Wildlife Magazine, Immediate Media Company, UK

Editorial responsibility: Robert Harcourt, Sydney, New South Wales, Australia
Wege M, Tosh CA, de Bruyn PJN, Bester MN (2016) Crossseasonal foraging site fidelity of subantarctic fur seals: implications for marine conservation areas. Mar Ecol Prog Ser 554:225-239

Witt MJ, Åkesson S, Broderick AC, Coyne MS and others (2010) Assessing accuracy and utility of satellite-tracking data using Argos-linked Fastloc-GPS. Anim Behav 80: 571-581

Witt MJ, Hardy T, Johnson L, McClellan CM and others (2012) Basking sharks in the northeast Atlantic: spatiotemporal trends from sightings in UK waters. Mar Ecol Prog Ser 459:121-134

Witt MJ, Doherty PD, Godley BJ, Graham RT and others (2016) Basking shark satellite tagging project: insights into basking shark (Cetorhinus maximus) movement, distribution and behaviour using satellite telemetry. Final Report. Scottish Natural Heritage Commissioned Report No. 908. Scottish Natural Heritage, Inverness

*Worm B, Lotze HK, Myers RA (2003) Predator diversity hotspots in the blue ocean. Proc Natl Acad Sci USA 100: 9884-9888

Submitted: April 26, 2019; Accepted: November 28, 2019 Proofs received from author(s): February 5, 2020 